\title{
Al-Magrizi Inflation Theory of Islamic Monetary Policy Implementation in Indonesia
}

\author{
Safarinda Imani \\ University of Ibrahimy Situbondo \\ safarinda.imani@gmail.com
}

Ridan Muhtadi

STAI Miftahul Ulum Pamekasan ridanmuhtadi@gmail.com

Hendri Husein Winari

Airlangga University

\begin{tabular}{ll}
\hline Submitted & $: 09-06-2020$ \\
Accepted & $: 01-12-2020$ \\
Published & $: 08-01-2021$
\end{tabular}

\begin{abstract}
During the time of Imam al-Magrizi (766-845 H), inflation had occurred in Egypt. AlMagrizi shows about the theory of inflation. Inflation becomes a discourse that studied heavily in the subject of the economy. Al-Magrizi is an Islamic economic thought who did a particular study of money and inflation. The paper focused on al-Magrizi inflation theory caused by two factors, namely natural factors and human error factors. To solve these factors, a nation could apply Islamic monetary policy to Umar Chapra's thought, namely a credit-oriented (financing) location as a solution of natural factor theory. Also, moral suasion or moral appeals as a solution to the human factor inflation theory.
\end{abstract}

Keywords: Inflation theory, Islamic monetary policy, Al Magrizi, Umar Chapra, Islamic economics

\section{A. Introduction}

The economic policy affects all movements in order to maintain stability. Within, a monetary policy aims to maintain price stability and regulate the high and low levels of inflation. There are two monetary policy strategies, namely, expansionary monetary policy and monetary policy contractive (Endri, 2008). One problem in economic matters is inflation (Suprayitno, 2005).

Sukirno (2011) said monetary policy is one of the macroeconomic policies aimed at directing macroeconomics in a better direction. In regulating circulation, the amount of money circulating in the middle of society then distributes to the monetary authority. Islamic monetary policy is one solution when inflation occurs. During Imam al-Magrizi $(766-845 \mathrm{H})$ time, inflation had happened in Egypt (Kato, 2012).

Al-Magrizi shows about the theory of inflation. According to Abidin (1978) AlMagrizi is an Islamic economic thought who did a particular study of money and inflation. 
Armed with adequate experience as a Muhtasib (market watchdog), this Muslim scholar correlates with the events of inflation that hit a country (Rusydiana, 2009).

Boediono (1995) said inflation is one of the characteristics of the Indonesian economy. Inflation data is more complex today than it was during the medieval era when inflation also existed. Today's complexity is due to the development of the financial industry that is proliferating. Following is an example of an inflation report in a very new era, to see the development of the inflation rate in 2016-2017

Table 1. Inflation Report (Consumer Price Index) Based on Annual Inflation Calculation

\begin{tabular}{|c|c|}
\hline Month year & Inflation rate \\
\hline May 2017 & $4.33 \%$ \\
\hline April 2017 & $4.17 \%$ \\
\hline March 2017 & $3.61 \%$ \\
\hline February 2017 & $3.83 \%$ \\
\hline January 2017 & $3.49 \%$ \\
\hline December 2016 & $3.02 \%$ \\
\hline November 2016 & $3.58 \%$ \\
\hline October 2016 & $3.31 \%$ \\
\hline September 2016 & $3.07 \%$ \\
\hline August 2016 & $2.79 \%$ \\
\hline July 2016 & $3.21 \%$ \\
\hline June 2016 & $3.45 \%$ \\
\hline May 2016 & $3.33 \%$ \\
\hline April 2016 & $3.60 \%$ \\
\hline March 2016 & $4.45 \%$ \\
\hline February 2016 & $4.42 \%$ \\
\hline January 2016 & $4.14 \%$ \\
\hline
\end{tabular}

Source: Bank Indonesia, www.bi.go.id/en/moneter/inflasi/data/Default.aspx

Table 1, between 2016 and 2017, inflation in Indonesia is classified as below 10\% per year. This figure demonstrates mild inflation. This classification is due to a theory of inflation that separates it into three categories, namely; (1.) Low inflation, or single-digit inflation (single-digit inflation), is inflation below 10\%. This inflation is still considered normal. In this inflation range, people still believe in money and still want to hold cash. (2) Galloping inflation, or double-digit or even triple-digit inflation, is defined as 20\%-200\% per year. This inflation occurs because of a weak government, war, revolution, or other events that cause the stock not to be available. At the same time, money is abundant, so people do not believe in cash. (3) Hyperinflation, which is inflation above 200\% per year. Under these circumstances, people do not think so in cash. It is better to spend money and save on goods than to keep the money. This is like saving gold, land, buildings, which of these goods will experience an equivalent price increase or even higher than inflation. Kato (2012) explained, in 
contrast to the classical and medieval periods (at the time of al-Magrizi), inflation occurred due to natural factors and human error factors.

Inflation is a phenomenon because it deteriorates the monetary unit value toward a commodity (Bank Indonesia, 2018). In overcoming the inflation that happened in the Middle Ages during al-Magrizi, the solution was the Islamic monetary instruments. Al-Magrizi discussed the theory of inflation, which is then implemented in Islamic monetary policy. It aims to answer the inflation theory and provide a solution to Islamic monetary policy (Karim, 2001).

\section{B. Literature Review}

\section{Biography of Imam al-Magrixzi}

The full name of Al-Magrizi is Taqiyuddin Al-Abbas Ahmad bin Ali Abdil Qadir AlHusaini, born in Barjuwan Village, Cairo in 766 H (1364 AD). His family came from Maqarizah, a village located in the city of Ba'lakbak. Maqarizah means remote from the city; therefore, it tends to be known as Al-Maqrizi (Nur, 2010: 288-289).

His father's weak economic condition caused Al-Magrizi's childhood and teenage education to be under the responsibility of his maternal grandfather, Hanafi ibn Sa'igh, an adherent of the Hanafi school thought. Al-Magrizi grew up based on this school (Dewan RedaksiEnsiklopedi Islam. 1999:42). After his grandfather passed away in 786 H (1384 AD), Al_Maqrizi switched to the Shafi'i school. Even in the development of his thought, he seemed inclined to adhere to the Zhahiri school (Karim, 2001)

Al-Magrizi is a person who loves Science. Since childhood, he likes to do scientific rihlah. He studied various disciplines, such as jurisprudence, hadith, and history, from the great scholars who lived in his time. Among the famous figures who greatly influenced his thinking was Ibn Khaldun, a great ulama 'and social sciences originator, including economics (Nur, 2010). His interaction with Ibn Khaldun began when Abu Al-iqrishad settled in Cairo and assumed the post of the supreme judge (Qadhi Al-Qudah) of the Maliki school during the reign of Sultan Barquq (784$801 \mathrm{H}$ ). Al-Magrizi died in Cairo on the 27th of Ramadan $845 \mathrm{H}$ or coincided with the 9th February 1422 AD Karim, 2001).

According to Mushtafa (1990) Al-Magrizi's works have three significant books; the first, a book that discusses world history, such as al-khabar 'an al-Basyr. Secondly, books that explain general Islamic history, such as the book of al-Darurar al-Mudhi'ah fi Date of al-Daulah al-Islamiyyah. Third, the book describes Egypt's history in the Islamic era, like us al-Mawa'izwa al-I'tibar bi Dhikr alKhithathwa al-Atsar, the book Iti'azh al Hubafa bi Dzikir al-A 'immah al Fathi.

\section{Discussion}

This section will address three main issues that are stipulated above. This discussion section will cover the big picture of the program in the form of Business Model Canvas, the general program procedure, and the sharia issue of this program at a glance.

\section{Theory of Inflation in the Al-Maqrizi Period}

From the famine that happened in Egypt, Al-Magrizi stated that the inflation event was a natural phenomenon that had befallen people's lives worldwide from the past until now. According to him, it occurs when prices generally increase and continue. When the 
supply of goods and services is experiencing scarcity, consumers must spend more money on the same goods and services because consumers need them.

In the following description, Al-Magrizi discusses the problem of inflation in more detail. He classifies inflation based on its causal factors: inflation caused by natural elements and inflation caused by human error (Karim, 2010). According to Gunawan (2003), the emergence of inflation due to a personality crisis, a crisis of faith, moral crisis, and a materialistic lifestyle.

\section{Natural Inflation}

As the name implies, this type of inflation is caused by various natural factors that humans cannot avoid. According to Al-Maqrizi, when a natural disaster occurs, various foodstuffs and other crops experience crop failure, so these items' supply causes a very drastic decline, and scarcity occurs. On the other hand, because of its very significant nature in life, the demand for these goods has increased. Prices soared, far exceeding people's purchasing power. This has significant implications for the expenses of various other goods and services. As a result, economic transactions have stalled, even stopped altogether, which eventually led to famine, plague, and death (Huda, 2009).

\section{Inflation due to human error}

In addition to natural factors, Al-Magrizi stated that inflation could occur due to human error. He has identified three things that cause this second type of inflation: corruption and poor administration, excessive taxation, and increased money circulation (Karim, 2010).

\section{Corruption and Poor Administration}

Al-Magrizi stated that government officials' appointment based on bribery and not because of capability would place people who do not have credibility in important and respectable positions both among the legislative, judicial, and executive. They are willing to mortgage all their possessions as compensation for the desired position and daily needs as officials.

When in power, these officials began to abuse power to achieve personal interests, fulfill their financial obligations, and the luxury of life. They try to collect as much wealth as possible by justifying all means. These officials' rampant injustice has made the conditions of the people increasingly concerned, so they were forced to leave the village and their jobs. As a result, there has been a drastic reduction in the population and labor force and the consequences of production, significantly impacting the decline in tax revenues and state revenues.

\section{Excess tax}

According to Al-Magrizi, due to corrupt mental officials' dominance in a government, the State expenditure experienced a drastic increase. As compensation, they implement a tax system that oppresses the people by imposing new taxes and raising the current tax rate. This dramatically affects the conditions of the farmers, who are the majority group in the community. Landowners who want to always be in fun will pass on 
the tax burden to farmers by increasing the cost of renting land. The pressure of officials and landowners on farmers becomes more significant and more intensive.

The frequency of various taxes for maintaining dams and similar works is increasing. Consequently, the costs for cultivating land, sowing seeds, harvesting crops are growing. In other words, the rice harvest produced under these conditions requires a higher price to exceed the farmers' reach.

The increase in prices, especially rice seeds, is almost impossible to decline because most rice seeds are owned by officials who are very hungry for wealth. As a result, farmers lose motivation to work and produce. They prefer to leave their homes and jobs rather than live in misery to become wanderers in rural areas. Thus, a decrease in the number of workers and increased idle land will affect production and other crops and ultimately lead to scarcity of food and rising prices.

\section{Increased Circulation Currency}

At first, currency that has intrinsic value is much smaller than the nominal value of the transaction is printed as a tool to meet the various needs of daily life were not significant. Therefore, this amount of currency is minimal in circulation.

When there was a budget deficit due to the bad behavior of the officials who spend state money for various personal and group interests, the government finally made massive money printing. According to Al-Maqrizi, the activity was expanded when the government's ambition to obtain large profits from printing currencies that did not require high production costs was increasingly out of control. As rulers, they issued a proclamation that forced the people to use the cash. The amount of money owed by the public is getting bigger, and circulation has increased sharply so that money has become the dominant currency. Furthermore, Al-Magrizi stated that the government's policy had implications for the existence of other currencies. Along with the enormous profits derived from printing money.

\section{Islamic Monetary Policy}

Umer Capra said the main objectives and functions of monetary policy within an Islamic economic framework are to achieve:

a. It extended economic equality with full employment and optimal economic growth.

b. It achieved socio-economic justice and wealth distribution and equitable income.

c. The stability of the currency's value allows the medium of exchange as a reliable unit, fair standards for future payments, and stable storage of values.

d. Increased mobility of savings funds - investments for economic development in a fair manner so that the return of profits can be guaranteed for all parties concerned.

e. Provided all forms of effective services usually expected from the banking system.

The elimination of interest and the application of LPS in Islam's monetary system will have fundamental implications for the policy instruments used.

Monetary policy is a policy used to control the amount of money in circulation by the Central Bank. The purpose of monetary policy is to maintain a stable internal and 
external value of money. The stability of the importance of cash reflects price stability that affects the realization of a country's development goals, such as meeting basic needs, equitable distribution, expanding employment opportunities, optimum real economic growth, and financial stability.

Islamic monetary policy objectives are no different from conventional monetary policy objectives: maintaining stability so that even economic growth is expected to be achieved. Stability in the value of money is inseparable from the purpose of sincerity and openness in dealing with humans.

\section{Analysis}

The program of "Lending Money For Garbage In Return" is modifying the existing Islamic Group Lending model, mostly based on the Qardul Hassan. The value proposition of this model as stipulated in Business Model Canvas above is to pay the loan with the garbage that has equal value to the instalment amount. For the IGL members, they will get the economic as well as the religious empowerment. At the same time, for the IGL operator side, this will result from value-added and the escalation of their business scale. The operator expectedly will have more income than before due to collecting garbage from the members and processing it to the new product. IGL operators' operation will also widen from only IMFI who gives loan to a social enterprise with lots more product to offer to the end-user. After the recycling process, the IGL Operator might use the market place's network to deliver the product to the end-user (both individual and industry).

\section{Inflation in Monetary Policy}

Inflation is a state of the economy characterized by rapidly rising prices that impact declining purchasing power. Decreased savings and investment often follow inflation due to increased public consumption and only little long-term savings. Al-Magrizi stated that the inflation event was a natural phenomenon that had befallen people's lives worldwide from the past until now. According to Al-Magrizi, inflation occurs when prices generally increase and continue continuously. At that time, the supply of goods and services experienced scarcity. So one of the ways to overcome inflation is monetary policy.

In monetary policy, several interest-free instruments can be used by central banks to increase or decrease the money supply. The abolition of the interest system does not prevent it from controlling the money supply in the economy.

There are several monetary policy instruments in the Islamic economy, including:

a. Moral Encouragement Policy: a policy that contains an announcement to all commercial banks to invite or prohibit to provide savings or savings loans.

b. Lending ratio: the policy to provide loans, Lending Ratio in this case, which means Qardhul Hasan (loan goodness).

c. Profit-Sharing: The profit ratio must be determined before starting a business. The Central Bank uses policy in monetary policy. Where when the central bank increases the amount of money in circulation, the profits for customers also increase

d. Islamic Sukuk: issuing Sukuk so that the money supply is reduced. So Sukuk is useful for reducing or increasing the money in circulation 
e. Government Instrument Certificate: is a replacement for Bank Indonesia certificates because SBI has an interest and is strictly prohibited in Islamic Banks

f. Reserve Ratio: A certain percentage of bank deposits must be held by the central bank; for example, $5 \%$. If the central bank wants to control the money supply, it can increase the Reserve Ratio, for example, from 5 percent to 20\%, with the effect that there is less money left on commercial banks, and vice versa.

g. Refinance Ratio: This is a proportion of the interest-free loan. When the refinance ratio increases, the financing provided increases, and when the refinance ratio falls, commercial banks must be careful because they are not encouraged to give loans.

The sale or purchase of a central bank certificate in a commercial framework is referred to as Treasury Bills. This instrument was issued by the Minister of Finance and sold by the central bank to brokers in large quantities, in the short term, and at a small interest rate. These Treasury Bills cannot be accepted in Islam, so the government issued an interest-free replacement system, called the GIC (Government Instrument Certificate).

The instruments required in Islamic monetary policy are expected to help regulate the supply of money in tune with the real demand for money and fulfill the need to finance a genuine government deficit and achieve other Islamic societies' socio-economic goals. There are some elements to regulate this, including (Chapra, 2000):

1. Growth targets in $\mathrm{M}$ and $\mathrm{MO}$

2. Public share of show deposits (demand deposits)

3. Official mandatory backup

4. Credit limit

5. Credit allocation ( financing) value-oriented

6. Other Techniques. Other weapons must supplement the qualitative and quantitative techniques above to realize the required targets, including the moral suasion or moral appeal.

\section{School of Monetary Policy Instruments in Islamic Economics}

Some schools of monetary policy instruments in Islamic economics, among others (Manan, 2012):

a. The first school ( Iqtishaduna)

There was no need for a monetary policy in the early days of Islam because the banking system was almost non-existent, and money was minimal. So, there is no sufficient reason to make changes to the offer of cash through discretionary. Also, credit has no role in creating money because credit is only used among traders. Furthermore, government regulations on letter borrowing ( promissory notes) and negotiation instruments (negotiable instruments ) are designed not to allow the creation of money.

Promissory notes or bill exchanges can be issued to buy goods and services or get some new funds but cannot be used for credit purposes. These rules affect the balance between the 
goods market and the money market based on cash transactions. In nasi'a or other transaction rules, money paid or received aims to obtain commodities or services.

Another instrument that is currently used to regulate the amount of money in circulation and to regulate short-term interest rates is OMO (the sale and purchase of government securities) that were not yet known in the early days of the Islamic government. Also, raising or lowering interest rates is contrary to Islamic teachings that prohibit the practice of usury.

b. Second School (Mainstream )

The objective of government monetary policy is to maximize the allocation of resources for productive economic activities. The Koran forbids accumulating money (money hoarding ) because making money does not benefit people's welfare. Therefore, this school designs a policy instrument aimed at influencing the size of the demand for money to be reversed to increase overall economic productivity. Market in the Islamic motifs grouped in two motifs transactions ( transactions motive) and motive guard ( precautionary motive).

The more money that is unemployed (idle) means the demand for money just in case the more significant. At the same time, the higher the tax levied on unemployed money is inversely proportional to the need for money only in case. Dues of idle funds are policy instruments that are imposed on all productive assets that are unemployed.

\section{Previous research}

Inflation in the Socio-Economic Phenomenon: According to Al-Maqrizi, written by AmbokPangiuk, State Islamic Religion Institute (IAIN) SultahanThaha Saifuddin Jambi, Contextualita, Vol. 28, No. 1, 2013. The study results are, Based on the classification of strata by Al-Magrizi that analysis of socio-economic phenomena and the impact of inflation depends on the nature of income (income) and wealth ( wealth) of each group. According to al Maqrizi, this theory needs to be tested through various literary processes and practices in the concept of inflation. However, in this study, many ideas have proven the socioeconomic phenomena that occur in society.

Monetary policy in the Sharia Economic Perspective, written by Nur Aini Latifah. The results showed that there are four main instruments used to regulate the amount of money in circulation: Open market operations ( Open Market Operations), discounted Facility ( Discount Rate), the mandatory reserve ratio (Reserve Requirement Ratio), Appeal Moral ( Moral Persuasion). There are several monetary policy instruments in the Islamic economy, including the Reserve Ratio. Moral Suassion, Lending Ratio, Refinance Ratio, Profit Sharing Ratio, Islamic Sukuk, Government Investment Certificate, Mutual Funds

\section{Al-Magrizi's Inflation Theory and Monetary Policy}

Seeing the real cause of the increase in the inflation rate due to weather factors, the problem is even and is the same in the minds of one Muslim scientist, Al-Maqrizi. In the history of Islamic economic thought, according to Al-Magrizi, inflation is caused by two 
things, namely; (1) inflation caused by natural factors (natural inflation), (2) inflation caused by human error (human error inflation).

The theory of inflation in the period of al-magrizi can be overcome with sharia monetary policy as a solution to inflation. Through policy instruments, the following is the problem of inflation in al-Magrizi's thinking:

1. Natural factor inflation

For arbitrary due to catastrophic crop failure resulting in inventory down and there is a shortage, the government issued a large number of funds that resulted in the state treasury decreased dramatically since the government did not get meaningful income. In other words, the government experiences a deficit in the State budget both politically, economically, and socially and becomes unstable, which then causes the collapse of a government.

The solution in this case only happens naturally, namely, when the situation has returned to normal, the supply of goods is significant, the demand has increased sharply. As a result, the prices of goods have risen and include wages and salaries of employees.

In the monetary policy Chapra solution that can be applied, it can be used in natural factor inflation, where the government provides credit allocations ( financing ) oriented to Islamic values. It can cope at the stage of crop failure only and for other impacts can be mitigated.

2. Inflation due to human error

a. Corruption and poor administration

As a result, government officials were no longer free from the intervention and intrigue of court cronies. Officials are not only sentenced every time but also confiscated his wealth, even executed. This condition subsequently greatly influenced the morale and efficiency of civil and military administration.

b. Excessive taxation

The cause is dominated by mentally corrupt officials so that state spending rises and applies a tax system and raise taxes so that farmers' impact will be taxed on land rent. Therefore the right solution is to replace the tax instrument with zakat, or the land lease tax especially applies but does not exceed the farmers' abilities.

c. Increased circulation of money

The government stopped printing silver as a currency. Even as one of the implications of officials' lifestyle, some dirhams owned by the community are melted into jewelry. As a result, the dirham currency is scarce and disappears from circulation, while the dinar currency is still in circulation even though a handful of people only owns it.

This situation places money as the value standard for most goods and services. AlMagrizi's policy on a large-scale printing of money has dramatically influenced the currency's value. As a result, money is no longer valuable, and prices soar, which in turn causes scarcity of food.

According to Umar Chapra, monetary policy in tackling inflation due to human factors uses moral suasion or moral appeal. The ethical appeal is a financial policy to regulate the money supply by appealing to economic actors, which can be implemented 
when there is an increase in money circulation. The objective of Islamic monetary policy is no different from the conventional monetary policy objective of maintaining the currency's stability (both internally and externally) so that equitable economic growth is expected to be achieved. Stability in the value of money is inseparable from the purpose of sincerity and openness in dealing with humans, utilizing no more mental corruption, which results in and impacts on excessive taxation on al-magrizi theory. This is mentioned in the Qur'an in the QS.Al.An'am: 152

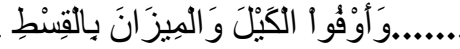 \\ "... And complete the measurements and scales fairly ..." \\ E. Conclussion}

Al-Magrizi stated that the inflation event was a natural phenomenon that had befallen people's lives throughout the world from ancient times to the present. According to him, it occurs when prices generally increase and continue. When the supply of goods and services is experiencing scarcity, and because consumers really need it, consumers must spend more money on the same goods and services.

In the following description, Al-Magrizi discusses the problem of inflation in more detail. He classifies inflation based on its causal factors into two things, namely inflation caused by natural elements and inflation caused by human error

In applying Islamic monetary policy to the Chapra for the solution of al-Mugrazi's inflation theory, it can be overcome by several ways of monetary policy, including a location-oriented credit (financing) as a solution of natural factor theory. Also, moral suasion or moral appeals as a solution to the human factor inflation theory.

\section{Bibliography}

Abidin, Zainal, Dasar-dasarEkonomi Islam, Jakarta: Bulan Bintang, 1979.

Adiwarman A. Karim, Sejarah PemikiranEkonomi Islam., Jakarta: GemaInsani Press, 2001 , Ekonomi Makro Islam, Jakarta: Raja GrafindoPersada, 2010.

Bank Indonesia, "PengenalanInflasi," sumberdari https://www.bi.go.id/id/ moneter/inflasi/pengenalan/Contents/Defaultaspx,diakses pada tanggal 15 April 2020.

Boediono, Ekonomi Makro. Seri SinopsisPengantarllmuEkonomi, No. 2 Edisi 4. Yogyakarta: BPFE Yogyakarta. 1995

Dewan RedaksiEnsiklopedi Islam, SuplemenEnsiklopedi Islam,Jilid2, Jakarta: PT IchtiarBaru Van Hoeve, 1999

Endri, E. "AnalisisFaktor- Faktor yang MempengaruhiInflasi di Indonesia." Eonomic Journal of Emerging Markets. Vol. 13 No. 1.2008.

Gunawan, Eddi. "BeberapaPenyelesaianInflasiMenurutSistemKeuangan Islam di Indonesia." ISEFID Review. Vol. 2 No. 1.2003

Huda, N., Nasution, M. E., \& Idris, H. R. Ekonomi Makro Islam PendekatanTeoritis. Jakarta: KencanaPrenada Media Group. 2009.

Kato, Hiroshi. "Reconsidering al-Maqrīzi's View on Money in Medieval Egypt," Mediterranean World. Vol. 21.2012.

Latifa, Nur Aini, KebijaknMoneterdalamPerspektifEkonomi Syariah., JurnalDosenEkonomiBisnis FEBI IAIN Tulungagung

Manan, Abdul, HukumEkonomi Syariah, Jakarta: Kencana, 2012). 
Mushtafa,Shakir.al-tarikh al-'Arabi wa al-Muarrikhun, Dirasah fi Tatawwur 'ilm al-Tarikh wa Ma'rifah Rijalih fi al-Islam, jilid 3. Beirut: Dar al-'Ilm li al-Malayin, 1990

Nur Chamid, Jejak langkah Sejarah Pemikiran Ekonomi Islam, Yogyakarta: Pustaka Pelajar, 2010

Pangiuk, Ambok, Inflasi pada Fenomena Sosial Ekonomi: Menurut Al-Maqrizi, Kontekstualita, Jambi: Jurnal IAIN Sulthan Thaha Saifuddin. Vol. 28, No. 1, 2013.

Rusydiana,AamSlamet. "DeterminanInflasi Indonesia: PerbandinganPendekatan Islam dan Konvensional," JIBE: Journal of Islamic Business and Economics, Vol. 3 No.1 2009

Samuelson, Paul A. dan William D. Nordhaus, IlmuMakroekonomi. EdisiKetujuhbelas. Jakarta: PT. Media Global Edukasi, 2004.

Sukirno, Sadono. Makro EkonomiTeoriPengantar. Jakarta: Rajawali Pers. EdisiKetiga.I. 2011

Suprayitno, Eko, Ekonomi Islam, PendekatanEkonomi Makro Islam dan Konvensional, Yogyakarta: GrahaIlmu, 2005.

UmerChapra. SistemMoneter Islam- Penerjemah Ikhwan Abidin B. Judulash Towards a Just Monetary System'. Jakarta: GemaInsani Press, 2000

www.bi.go.id/id/moneter/inflasi/data/Default.aspx (diakses pada tanggal 13 February, 12.00) 